\title{
3D Modelling and Virtual Reality as a Cataloguing Alternative of Light Environments and their Application in Museums
}

\author{
Leticia Crespillo Marí \\ Universidad de Málaga \\ Bulevar Louis Pasteur, 27, 29010 \\ Campus de Teatinos, Málaga, Spain \\ Icrespillom@uma.es
}

\section{INTRODUCTION}

Light is an active agent that allows artistic experiments in space due to its immaterial nature. In these three-dimensional spaces, the lighting element is able to establish a dialogue with the viewer. Its effects of shadow, volume and, its organization in space help the subject to access the meaning of certain conceptual Works, where there is an event that requires a true intellectual understanding. This phenomenological event is experienced by the body in its journey, in a processual, sensory and experiential way. There is no figurative reference, only a total space that surrounds the spectator: a "conceptual threshold" where the idea goes beyond objects and space is meant.

In the 60 s and 70 s of the twentieth century, there was a transformation of space. Temporal abstraction - as Peter Osborne tells us - defines an experience whose meaning is in the subject. The concept of "place-art" supposes a rupture with tradition, and new less visual and metaphysical questions are formulated.

The minimalist installations offer spatial and architectural proposals of experience. It was a great qualitative leap in the consideration of sculpture, since it marks very well the concept of experience before a phenomenon that is perceived during the course of time. The visual, physical and significance of events, attracts the viewer's attention and gaze towards the "absence", generating physical and sensual emotions. These sculptures, installations and minimalist spaces, and, more specifically, those artistic light installations (minimal light art) are the main object of study of this paper. Installations like those of James Turrell, Dan Flavin, Olafur Eliasson, Ann Veronica Janssens, Anthony McCall, Carlo
Bernardini, Lucio Fontana or Robert Irwin, among others, help us to understand the process of creation and experimentation of these Works in order to develop a alternative cataloguing prototype that improves its reception, from the point of view of the museography and the catalogue.

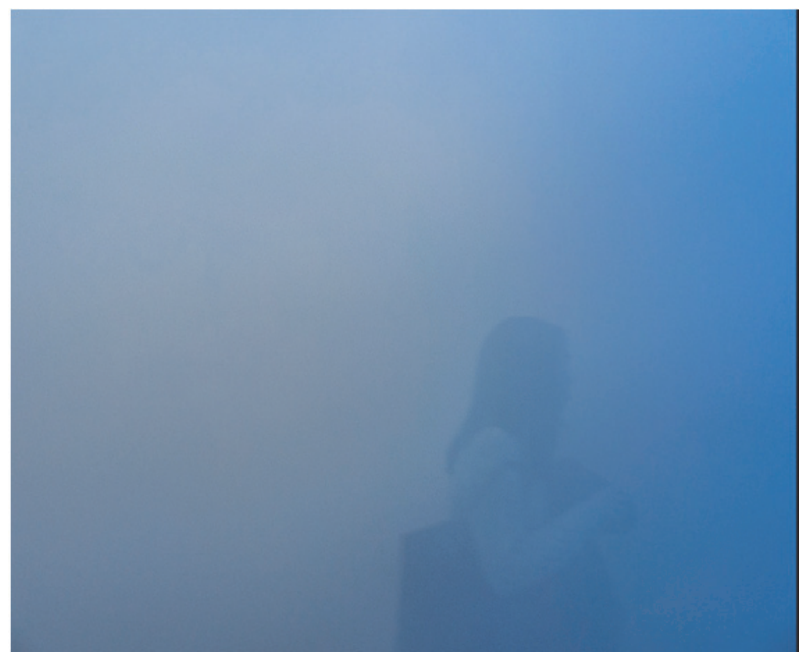

Figure 1: Ann Verónica Janssens Environment. Daylight blue, sky blue, médium blue, yellow (2011). National Galeies nationales du Gran Palais, Paris, April 10-July 22, 2013. Image: Yann Caradec.

\section{CONTEMPORARY MINIMAL LIGHT ART INSTALLATION AND ENVIRONMENTS}

Many artists, who worked with contemporary Light Art, also worked on the performative and the processual. Through these sculptures and installations, the necessary participation of the spectator in the artistic act, is established. These interventions in space require an active spectator, an action, a reaction and, therefore, a physical presence for their aesthetic experimentation. The 
work generates a relationship with the viewer, which allows him to interpret the speech. This conceptual development is linked to the plastic language of light, offering new discourses in the twentieth-century Europe that, today, continue to develop from new materials and techniques as, for example, in the case of Yayoi Kusama and its installation Infinity Mirrored Room - Filled With the Brilliance of Life, at Tate Modern, 2012.

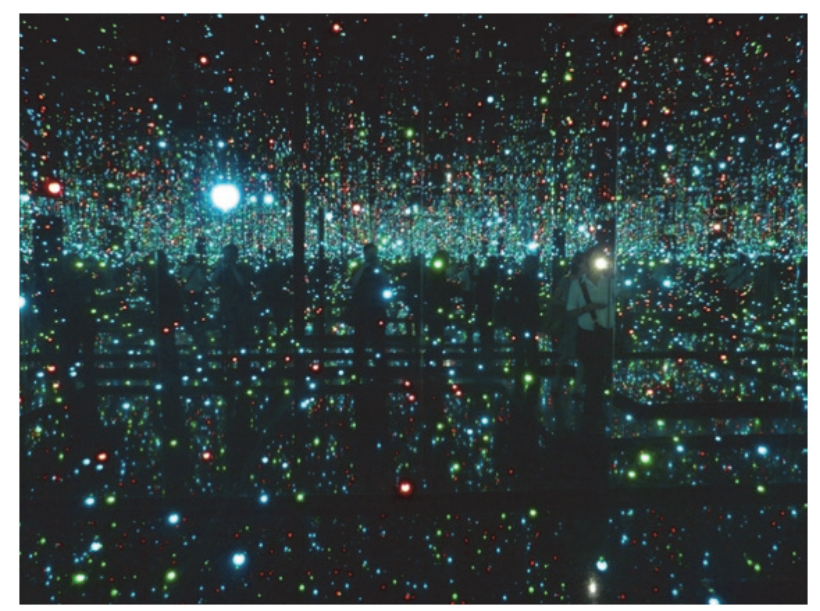

Figure 2: Infinity Mirrored Room - Filled With the Brilliance of Life, Tate Modern, 2012. Image: Loz Pycock.

\section{VIRTUAL REALITY AS A DIDACTIC RESOURCE}

The theatricality that surrounds these types of interventions, is the key to raise the prototype of Virtual Reality. The traditional way in which the works are catalogued is insufficient for this type of intervention. Its aesthetic component goes beyond formal. Technology can help us to propose new tools with which to create knowledge and disseminate, from a didactic point of view, these types of artworks. After all, it is one of the objectives of a museum. These facilities or environments create subjective referential worlds that allow the subject to understand different elements of the world from their own perspective. Virtual reality is a new strategy of representation that brings the aesthetic experience to the viewer and, allows him or her, to participate in the work immersively. Digital technology facilitates the development of architectural spaces designed to be experienced.

The interactive museography must value the artwork from a new perspective. Interactivity and virtuality help to establish dialogues with users, so that they can participate in the diverse experiences that the museum offers them. Virtual reality is a tool that involves navigation in real time, sensory immersion and implicit interaction with the model itself. Thus, a perception of 'presence' necessary for the complete and correct reception of these types of interventions, is obtained. The museum, therefore, must develop museographic strategies in accordance with the needs and sensibilities of our time. In our case, the catalogue must be renewed using the advanced techniques of image reproduction.

\section{EXAMPLE}

Dan Flavin's Untitled (To Helga and Carlo with respect and affection), 1974. Reconstructed by Opossum Studios Virtual Builders \& Leticia Crespillo Marí.

Dan Flavin defended Art as thought, therefore, dematerialised the work through light and its physical-material conditions. The transformation of the indoor space given by architecture, offers as a paradox, a place that only exists for the created work. The sensory activity of the spectator is intense, since it is involved in a movement of participation, and driven by the exploration of the aesthetic phenomenon. These artistic projects change and decontextualise the environment perceptively and, that, from the History of Art, are studied as paradigmatic cases.

\section{ACKNOLWEDGEMENTS}

This text is part of the research results of the Spanish National Project ARTCATALOG, Catálogos artísticos: Gnoseologías, epistemologías y redes de conocimiento. Análisis crítico y computacional HAR2014-51915. It has been possible thanks to the help of the University of Málaga (Ayuda Predoctoral del Plan propio de Investigación de la UMA).

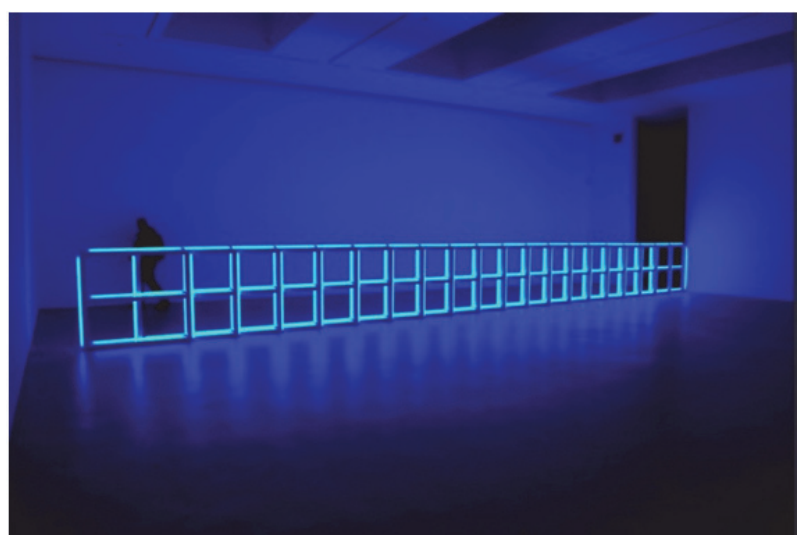

Figure 3: Dan Flavin, Untitled (to Helga and Carlo, with respect and affection) [Installation view] 1974. Dan

Flavin, Series and Progressions, at David Zwirner, Dec. 19, 2009. Image: Andrew Russeth. 


\section{REFERENCES}

Arnheim, R. (2013) Arte y percepción visual. Madrid: Alianza Editorial S.A

López Benito, V. (2014) El uso de los medios digitales y la subjetividad en el campo de la educacion en el arte. In Santracana Mestre, J. Y Martín Piñol, C. Educación, tecnología y patrimonio cultural: para una educación inclusiva. Trea, Asturias.

Maderuelo, J. (2003) La idea del espacio en la arquitectura y el arte contemporáneo 1960-1989. Madrid: Akal S.A.

Osborne, P. (2010) El arte más allá de la estética. Ensayos filosóficos sobre el arte contemporáneo. Cendeac, Murcia.

Ring Petersen, A. (2015) Installation Art Between Image and Stage. Museum Tusculanum Press, Copenhange.

Suárez, J. I. (2010) Escenografía aumentada, teatro y realidad virtual. Editorial Fundamentos, Madrid.

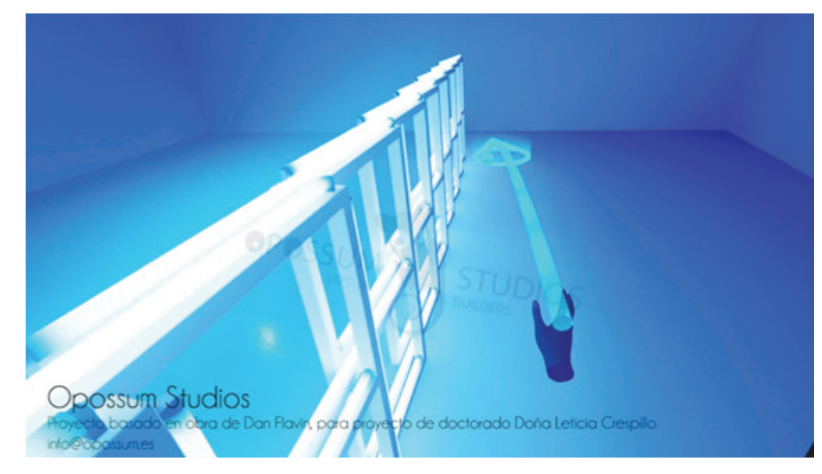

Figure 4: First Test model (Leticia Crespillo Marís Phd Project). Reconstruction of Dan Flavin, Untitled (to Helga and Carlo with respect and affection), 1974. Authors:

Leticia Crespillo Mari/Gabriel Ruíz Gonzálvez (Opossum Studios Virtual Builders, Melilla-Spain) from Dan Flavin, Series and Progressions Catalog, David Zwirner Gallery, NY. 